\title{
Effect of Diet, Age, and Genetics on Rainbow Trout Growth and Fillet Quality
}

\author{
Bahareh Adami \\ West Virginia Univer, ba0047@mix.wvu.edu
}

Follow this and additional works at: https://researchrepository.wvu.edu/etd

Part of the Aquaculture and Fisheries Commons, and the Nutrition Commons

\section{Recommended Citation}

Adami, Bahareh, "Effect of Diet, Age, and Genetics on Rainbow Trout Growth and Fillet Quality" (2021). Graduate Theses, Dissertations, and Problem Reports. 8032.

https://researchrepository.wvu.edu/etd/8032

This Thesis is protected by copyright and/or related rights. It has been brought to you by the The Research Repository @ WVU with permission from the rights-holder(s). You are free to use this Thesis in any way that is permitted by the copyright and related rights legislation that applies to your use. For other uses you must obtain permission from the rights-holder(s) directly, unless additional rights are indicated by a Creative Commons license in the record and/ or on the work itself. This Thesis has been accepted for inclusion in WVU Graduate Theses, Dissertations, and Problem Reports collection by an authorized administrator of The Research Repository @ WVU. For more information, please contact researchrepository@mail.wvu.edu. 
Graduate Theses, Dissertations, and Problem Reports

2021

Effect of Diet, Age, and Genetics on Rainbow Trout Growth and Fillet Quality

Bahareh Adami

Follow this and additional works at: https://researchrepository.wvu.edu/etd

Part of the Aquaculture and Fisheries Commons, and the Nutrition Commons 
Effect of Diet, Age, and Genetics on Rainbow Trout Growth and Fillet Quality

\title{
Bahareh Adami
}

Thesis submitted to the

Davis College of Agriculture, Natural Resources, and Design

at West Virginia University

in partial fulfillment of the requirements

for the degree of

\author{
Master of Science \\ in \\ Animal and Food Sciences \\ P. Brett Kenney, Ph.D., Chair \\ Ida Holásková, Ph.D. \\ Eugene E. Felton, Ph.D.
}

\section{Division of Animal and Nutritional Sciences}

\author{
Morgantown, West Virginia \\ 2021
}

Keywords: rainbow trout, diet, age, family, fillet quality 


\begin{abstract}
Effect of Diet, Age, and Genetics on Rainbow Trout Growth and Fillet Quality

Bahareh Adami
\end{abstract}

In this study, analyses were conducted to compare fillet quality attributes of 4 rainbow trout families $(40,102,159$, and 187) fed fish meal (FM) and a fishmeal free diets (FMF), to two age endpoints, 9 and 11 months.

Previous studies with rainbow trout have evaluated effect of age, diet, and family on growth performance and fillet quality. However, comprehensive analysis of variables, is lacking for rainbow trout, one of the main aquatic foods for domestic and international consumers.

Separable muscle as a percent whole body weight was not affected by diet, family, age, and the interaction of these main effects.

Butterfly fillet as a percent of whole weight was affected by diet with a family-by-age interaction $(\mathrm{P}<0.05)$. Age affected fillet thickness of rainbow trout $(\mathrm{P}<0.05)$. In addition, fillet thickness was affected by the family-by-diet interaction $(\mathrm{P}<0.05)$. Percent intramuscular moisture and fat were affected by diet and family $(\mathrm{P}<0.05)$; whereas, ash content was not affected by diet, age, or family $(\mathrm{P}>0.05)$. Crude protein was higher in fish at 11 than at 9 months (adjusted pvalue $=0.01$ ). Raw Allo-Kramer shear force was higher at 11 months (adjusted $p$-value $=0.002$ ). Also, trout from family 187 had a higher shear force compared to families 40 and 159 (adjusted pvalue $=0.01$ and 0.005 , respectively). The family-by-age interaction was significant for cooked Allo-Kramer shear force $(\mathrm{P}<0.05)$. Average $\mathrm{a}^{*}$ value was affected by diet, family, and age $(\mathrm{P}<0.05)$, while average $\mathrm{b}^{*}$ value was not affected by diet, family, and age $(\mathrm{P}>0.05)$. A significant diet-by-family interaction was observed for $\mathrm{L}^{*}$ value $(\mathrm{P}<0.05)$. Cooked and raw fillet 
energy was higher at 11 than at 9 months (adjusted p-value $=0.0001$ and 0.0001 , respectively). Moreover, shear energy of cooked and raw fillets from fish fed the FM diet was higher (adjusted p-value $=0.0004$ and 0.0009 , respectively) compared to the FMF diet. Head-on-gutted (HOG) yield was affected by diet and the interaction of family-by-age $(\mathrm{P}<0.05)$. Overall, a FMF diet could replace with a FM diet without any negative effect on whole-body weight of rainbow trout, and replacement may improve select fillet qualities attributes. Lastly, there is a positive correlation between age and fillet quality attributes, $a^{*}$ value, belly flap thickness, fillet thickness, average protein, cooked energy, and raw energy.

This work provides supportive information for future evaluations of the effect of age, diet, and family on trout fillet quality attributes. 


\section{Acknowledgements}

First, I would like to thank my advisor, Dr. P. Brett Kenney, for taking a chance on me as a master's student. His support has given me the confidence to handle any task given. I would also like to take this time to thank my committee members, Dr. Eugene E. Felton and Dr. Ida Holásková for support and guidance in this study.

This study would not have been possible without the seamless collaboration with the National Center for Cool and Cold Water Aquaculture (NCCCWA; Leetown, WV).

I would like to express my gratitude to all the facilities employees for the opportunity and their help in rearing and care of the fish.

I would also like to thank Susan Slider, posthumously, for her assistance in conducting laboratory projects. Moreover, I would like to thank Areeya Towviriyakul who helped me throughout my journey.

I would like to express my gratitude to Dr. Beth Cleveland the USDA's National Center

for Cool and Cold Water Aquaculture and Mr. John Davidson of the Freshwater Institute (Shepherdstown, WV) for their collaboration.

Finally, I must express my heartfelt appreciation to my husband for all his love and support in all of my pursuits. In particular, I must thank my parents, for their continued love and support through all of my endeavors in life. 


\section{Contents}

Abstract iii

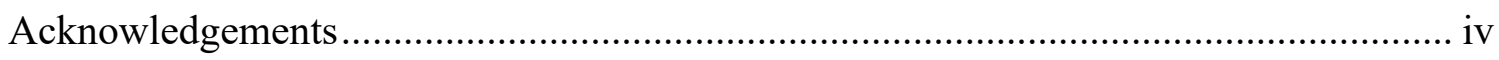

List of tables...................................................................................................... vii

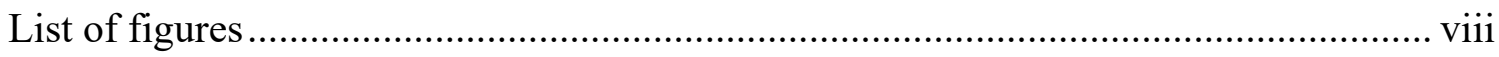

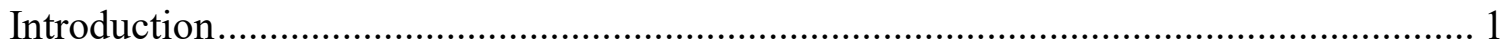

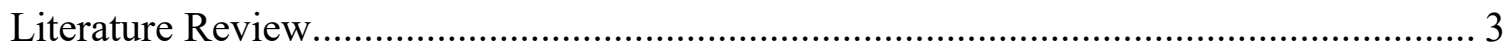

1.1 Adipose tissue in fish ........................................................................ 3

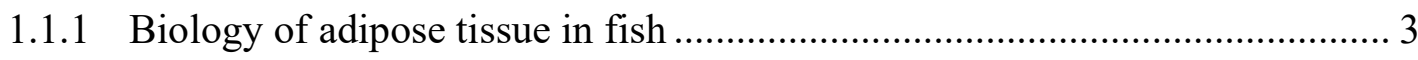

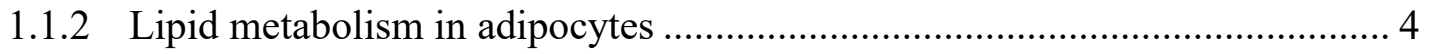

1.1.3 Accretion of adipose tissue in fish ................................................... 5

1.2 Modulation of adiposity by extrinsic and intrinsic factors............................. 6

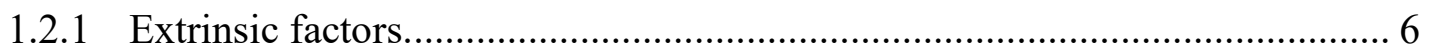

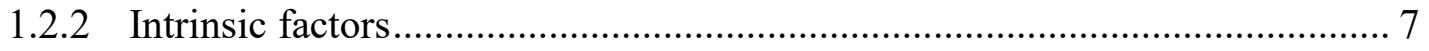

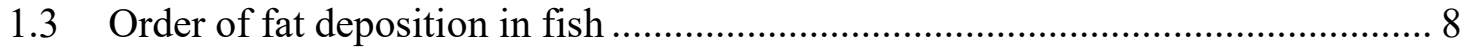

1.4 Effects of fatty acids on meat quality .................................................... 8

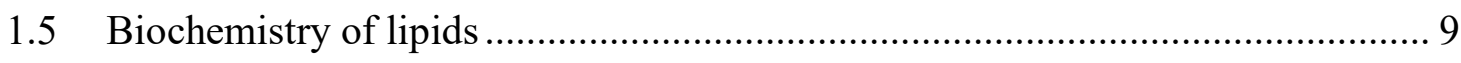

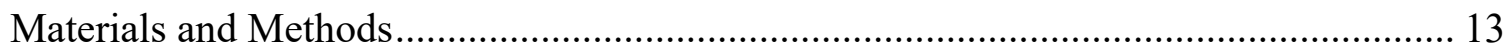

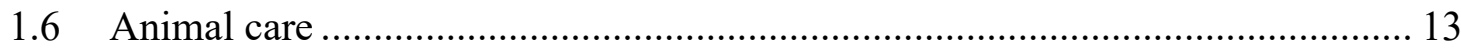

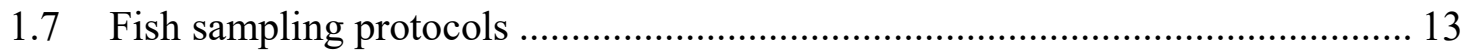




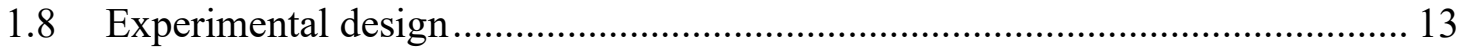

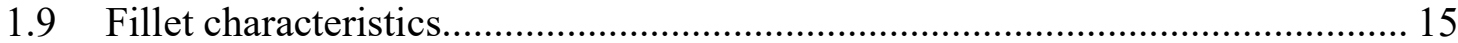

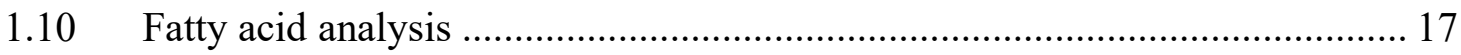

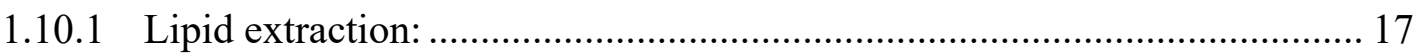

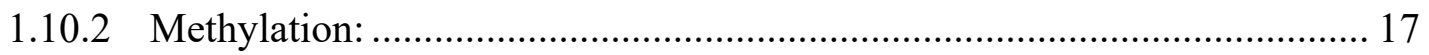

1.10.3 Fatty acid separation and quantification: .......................................... 18

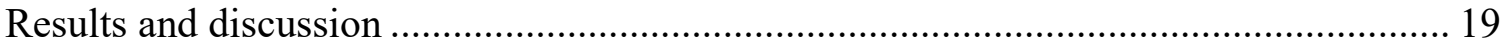

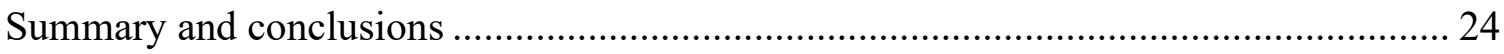

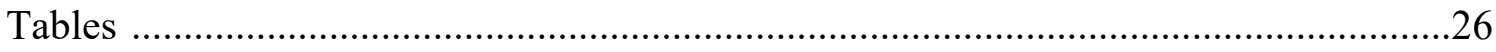

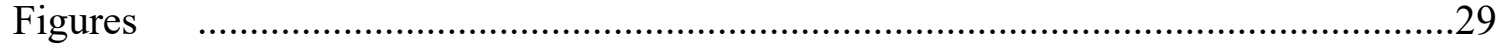

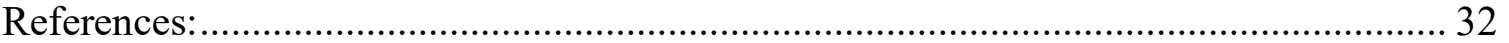




\section{List of tables}

Table 1. Rainbow trout fillet composition as affected by diet, family and age (LS Means \pm Standard Error) 26

Table 2.Energy yield for raw and cooked fillet of rainbow trout (LS Means \pm Standard

Error). 26

Table 3. formulation of the test (zero fishmeal/ low phosphorus) diet and the control (fish meal) diet 27 


\section{List of figures}

Figure 1. Effect of Family-by-Age Interaction (LS Means) on butterfly fillet as a percent of whole-body weight 29

Figure 2.Effect of Diet-by-Family Interaction (LS Means) on fillet thickness size of rainbow trout 29

Figure 3.Effect of Family-by-Age interaction (LS Means) on cooked shear force value of rainbow trout. 30

Figure 4.Effect of Diet-by-Family interaction (LS Means) on lightness (L*) value color of rainbow trout.

Figure 5.Effect of Family-by-Age interaction on head-on-gutted percent of rainbow trout 


\section{Introduction}

Fish fillets are a high-protein, low-fat food that provides a variety of health benefits. Oily fish are high in omega-3 fatty acids, which are important to human health (Karakatsouli, 2012). This nutritional attribute has increased the demand for fish. The aquaculture industry has evolved to address this demand (FAO, 2013) through land-based aquaculture production systems.

Based on the Food and Agriculture Organization of the United Nations (FAO), the production of salmonids, such as rainbow trout, has grown exponentially since the 1950s; the global aquaculture production of rainbow trout has increased in the last 20 years from 277,997 to 814,090 tons.

Due to aquaculture's growth and limited supply of fishmeal and fish oil, efficient use of sustainable feed ingredients has become increasingly important. Aquaculture industries have recognized that continued, high use of fishmeal is not economically sustainable, and there is need to identify alternatives to traditional fishmeal (Naylor et al., 2009, Gatlin et al., 2007).

A variety of potential diet ingredients has been introduced to the aquaculture industry. Feed ingredients that are local or regional in nature have been considered as fishmeal substitutes, including single cell proteins such as yeast, bacteria, and micro-algae (Bairagi et al., 2004; Ng et al., 2002; Wang et al., 2006).

Lupins, field peas, and any material that is not considered for human consumption could be used as ingredients in fish diets depending on compatibility with fish digestion (Glencross et al., 2011; Hernández et al., 2016). Animal by-products, such as meat and poultry products, are another source of ingredients, but phosphorus content may limit use. High-quality, poultry byproducts that are low in phosphorous and high in protein concentration (Sealey et al., 2011) may be appropriate for these diets. Mixed nut meal, wheat flour, and corn protein concentrate are 
protein ingredients that may substituted for fishmeal diet (Davidson et al., 2016). Plant-based products may be a reasonable protein source to replace fishmeal in the diets of fish species, such as rainbow trout. Plant-protein sources may include, plant-protein meals and plant-protein concentrates (Lim et al., 2009). Canola, soy, pea, barley, rice protein concentrates, along with wheat gluten meal, have all been tested as fishmeal replacements with varying degrees of success (Forster et al., 1999; Thiesses et al. 2003; Barrows et al., 2007; Lim et al., 2009; Gaylord and Barrows, 2009).

One concern during the rearing of rainbow trout is the effect of age on fillet yield and quality (Paaver et al., 2004). Relative to fish age, fat content increases with size. During sexual maturation, lipid content increases significantly at the start of gonadogenesis and subsequently decreases during gonadogenesis, reaching a minimum level after spawning. (Aussanasuwannakul et al., 2011; Weil et al., 2013).

Fertile, rainbow trout females develop ovaries, mobilizing energy and other stored nutrients to support egg growth (Aussanasuwannakul et al., 2011; Manor et al., 2014). Lipid and protein mobilization to support egg growth affects fillet quality and reduces muscle mass, measured as percent separable muscle (Salem et al., 2006). Decreased fillet lipid and protein content during this period diminishes quality and yield.

With limited knowledge of combined effects of diet, age, and genetics or family on fillet quality of rainbow trout, more research is needed. Specifically, there is limited research addressing the relationship between fishmeal alternatives and fillet quality as affected by age and genetics. The primary objective of this study was to determine the influence of family, age ( 9 and 11 months), and diet (fishmeal and fishmeal free) on percent separable muscle accumulation and fillet attributes of rainbow trout. 


\section{Literature Review}

\subsection{Adipose tissue in fish}

Lipids are the predominant source of energy for fish, and these animals store fat in adipose tissue depots throughout their body. Subcutaneous, peri-visceral, and intramuscular adipose tissues influence carcass composition and fillet yields. In addition, intramuscular fat affects organoleptic properties of fillet. Sheridan et al. (1988) mentioned that the major sites of fat deposition in fish are the perivisceral, muscle, and liver. Adipose tissue that influences carcass quality may be divided into discarded and consumed fat. Discarded fats are visceral fat, located in the abdominal cavity, and subcutaneous fat, just deep to the skin. Subcutaneous fat is more prominent dorsally and ventrally, at the midline. Dorsal subcutaneous fat is prevalent in a region between the head and the dorsal fin. In addition, ventral subcutaneous fat is located along the ventral midline. Consumed fat depots are in white and red muscle, and ninety percent of fish skeletal muscle is composed of white muscle.

\subsubsection{Biology of adipose tissue in fish}

White adipose tissue (WAT) is a specific type of connective tissue that contains neutrallipid-filled cells called adipocytes. Adipose tissue plays an important role in energy homeostasis in two ways: 1- regulation of adipocyte lipid turnover, and 2- the secretion of adipokines [e.g.adiponectin, leptin and tumor necrosis factor $\alpha(\mathrm{TNF} \alpha)$ ] that have an endocrine function and act on the central nervous system (CNS) and peripheral tissues to regulate processes such as appetite, glucose homeostasis and lipid metabolism. (Konige et al. 2014; Rutkowski et al. 2015; Salmerón et al. 2015). 
The main storage form of neutral lipid in fish is triglycerides (TG). Species, plane of nutrition, life-stage, and physiological state have a direct effect on the fat depot location (Flynn et al., 2009; He et al., 2015; Weil et al., 2013). The preferential lipid storage sites in fish are perivisceral, subcutaneous, intramuscular, and hepatic (Flynn et al., 2009; He et al., 2015; Weil et al., 2013). Moreover, Adipose Tissue in fish is a source of metabolic energy for growth, reproduction, embryonic and yolk-sac larval development, and swimming.

\subsubsection{Lipid metabolism in adipocytes}

Adipose tissue regulates lipid metabolism for several reasons. First, mature adipocytes create energy reserves throughout lipogenesis. They take FAs or other substrates (e.g. glucose or amino acids) from the diet and convert them into TG for long-term storage. Subsequently, when energy is required, TGs in fat cells break down into FAs and glycerol via lipolysis, and these FA's are released into the blood. Lipolysis and lipogenesis are regulated by the integration of endocrine and neural mechanisms that cooperate to maintain the relative constancy of body fat under normal conditions (Fonseca et al., 2006). The expression of these enzymes increases as part of the normal biochemical function of the mature adipocytes.

A third activity is beta-oxidation, a catabolic process by which fatty acid molecules are broken down in the mitochondria to generate acetyl-CoA; this intermediate enters the citric acid cycle. Resulting $\mathrm{NADH}+\mathrm{H}^{+}$is oxidized via the electron transport system to $\mathrm{NAD}^{+}$with concomitant generation of ATP as the energy currency for cell activity. Several hormones and growth factors, in concert with enzymes and transcription factors, regulate lipogenesis, lipolysis, and $\beta$-oxidation. 
Triglyceride is a triester of glycerol and three fatty acids molecules. The glycerol needed for TG synthesis comes from three different sources, Glycolysis, Glyceroneogenesis, and Phosphorylation (Proença et al., 2014).

Fatty acids for TG syntheses can be obtained from three different sources: 1- incorporation of FAs bound to albumin; 2- Hydrolysis of lipoproteins; and 3- Synthesis of FAs within the adipocyte from acetyl coenzyme-A subunits (Proença et al., 2014). Fatty acids from the first two sources are carried by the blood, using FA transporters, while the third source of FAs is the synthesis of acetyl-CoA and FAs from non-lipid precursors and is known as de novo lipogenesis (Proença et al., 2014).

\subsubsection{Accretion of adipose tissue in fish}

During adipocyte hyperplasia, formation of new adipocytes from precursor cells occurs, characterized by progenitor proliferation and differentiation. And, there are limitless possibilities for adipocyte recruitment from fibroblast-like cells when lipid storage space is needed during animal development.

In mammals and birds, hyperplasia is mostly complete at birth; whereas in fish, hyperplasia occurs during early life stages (Umino et al., 1996) as well as throughout life (Fauconneau et al., 1997; Spalding et al., 2008).

During adipocyte hypertrophy, lipid load in existing adipocytes increases due to excess caloric intake. In gilthead sea bream, fish were fed for 14 months with a fish oil diet and fish oil free diet containing $66 \%$ vegetable oil. Isolated adipocytes from fish fed the fish-oil-replacement diet exhibited increased lipolytic activity and adipocyte hypertrophy (Cruz-Garcia et al., 2011). Thus, fish on a high fat diet or on a diet containing a high percentage of vegetable oils expand their adipose tissue by adipocyte hypertrophy to create additional storage space for excess energy. A 
maximum fat cell size is reached within a population of adipocytes, and this change initiates a wave of recruitment of adipocytes for additional lipid storage space.

\subsection{Modulation of adiposity by extrinsic and intrinsic factors}

Both environmental (extrinsic) and intrinsic factors influence feeding behavior and feed intake, which in turn affect growth and adiposity of fish (Weil et al., 2013).

\subsubsection{Extrinsic factors}

Seven to 10 -week starvation decreased carcass and visceral lipids in white sturgeon. In addition, long-term starvation in rainbow trout causes lipid mobilization from the viscera as opposed to muscle and liver (Jezierska et al. 1982). Consistent with the effect of long-term starvation, short-term starvation ( 2 weeks) induced a decline in visceral fat in juvenile sea bass (Navarro and Gutie' rrez, 1995). Dietary fat levels influence body growth as well as fat deposition in different fish species. These studies support an order of adipose tissue mobilization different from order of mobilization in terrestrial food animal species. In terrestrial species, the order of mobilization would begin first from the intramuscular adipose tissue. In the context of aquaculture, high lipid diets increase fish adiposity; fillet moisture content is decreased without modifying protein content (Green and Selivonchick, 1987). In rainbow trout, dietary fat levels modulate fat deposition in viscera and carcasses, without a precise relationship to muscle lipid content or subcutaneous fat (Jobling et al., 1998). The effect of diet on visceral fat deposition, is related to fish body size in rainbow trout; hyperplasia and hypertrophy of adipocytes have been observed in small trout, while in larger trout, the response is due mostly to adipocyte hypertrophy (Ge'lineau et al., 2001).

Fish meal and fish meal free diets have received attention for many decades in aquaculture (Cho et al., 1974; Dabrowska and Wojno, 1977). Since the market price for fishmeal 
and fish oil has risen steadily due to static supply and increasing demand, the aquaculture industry has considered more economical and sustainable ingredients for use in aquafeeds (Tacon and Metian, 2008; Naylor et al., 2009; FAO, 2014). Therefore, a variety of alternatives have been introduced to the aquaculture industry, such as algal and bacterial proteins (Kiron et al., 2012), poultry by-product (Fowler,1991), nut meal (Barrows and Frost, 2014), and plant-derived proteins (Gatlin et al., 2007). Different studies have monitored the effect of plant-based proteins on aquaculture species (Salze et al., 2010). Research on rainbow trout (Oncorhynchus mykiss) showed that substitution of fishmeal with protein blends in a fishmeal free diet can result in comparable growth (Barrows et al., 2007; Davidson et al., 2013; Barrows and Frost, 2014).

Replacement of vegetable oil with fish oil differentially affected hypertrophy of adipocytes originating from dorsal or ventral locations in rainbow trout (Fauconneau et al.1997). In addition, visceral fat is influenced by replacement of fish oil with vegetable oil in different fish species. Replacement of fish oil by vegetable oil in gilthead sea bream promotes an increase in the adipocyte lipolytic activity by increasing hormone sensitive lipase (HSL) activity (Cruz-Garcia et al.2011).

\subsubsection{Intrinsic factors}

There is a positive relation between fat content and fish age; as fish age increases total lipid increases (Kiessling et al. 1991). Research addressing visceral fat content showed that muscle fat content increases with fish size in rainbow trout (Kiessling et al. 1991) as well as in post-smolt and older/larger Atlantic salmon (Jobling et al. 2002; Jobling and Johansen 2003). It appears that muscle is an important fat depot in salmonid species, characterized by a non-uniform distribution of lipids through the fillet (Katikou et al. 2001). 
Reproduction is an intrinsic factor that modulates adiposity. Studies in rainbow trout showed that dorsal, intramuscular lipid content increased significantly at the beginning of ovogenesis and spermatogenesis and then decreased during ovulation and spermiation (Weil et al. 2000). Aussanasuwannakul et al. (2011) reported that, during sexual maturation, fat content in diploid, fertile fish decreased to support egg development compared to triploid, sterile fish.

\subsection{Order of fat deposition in fish}

Progression of adipose tissue deposition occurs in specific regions referred to as adipose tissue depots. These regions form from an accumulation of adipocytes, the predominant cells of adipose tissue, and they develop at different times and at different rates.

Major lipid storage sites in fish are mesenteric adipose tissue, intramuscular adipose tissue, and liver. Cod, which are deep water feeders, have little lipid stored in skeletal muscle but considerable lipid stored in the liver. Rainbow trout, which are active surface feeders, have substantial amounts of lipid stored in skeletal muscle. Of the two skeletal muscle types, dark muscle stores more lipid than light muscle. Robinson and Mead (1973) showed that trout force fed palmitic acid incorporated radioactivity into dark muscle lipid at a 5-fold higher amount than in light muscle lipid.

\subsection{Effects of fatty acids on meat quality}

Fatty acids affect various muscle quality attributes. Fatty acid composition of the lipid affects melting point; saturated fatty acids have a higher melting point than unsaturated fatty acids. These differences are observed as oil in fish or solid fat in muscle foods from terrestrial species; in the $18 \mathrm{C}$ fatty acid series, stearic acid $(18: 0)$ melts at $69.6^{\circ} \mathrm{C}$, oleic acid $(18: 1)$ at $13.4^{\circ} \mathrm{C}, 18: 2$ at $-5^{\circ} \mathrm{C}$ and $18: 3$ at $-11^{\circ} \mathrm{C}$. Therefore, with increasing unsaturated fatty acids, melting point decreases (Wood et al. 2003). In addition, molecular structure alters melting point. Trans fatty acids melt at 
a higher temperature than their cis-isomers and branched chain fatty acids have lower melting points than straight chain fatty acids with the same number of carbon atoms (Enser, 1984).

Unsaturated fatty acids are more susceptible to peroxidation. Lipid peroxides generated from free-radical lipid oxidation contribute to color deterioration through oxidation of red oxymyoglobin to brown metmyoglobin. Moreover, oxidative deterioration of fats can result in off-flavor and off-odor development; lipid oxidation is a major reaction in foods that causes significant loss of quality.

\subsection{Biochemistry of lipids}

Lipids are a group of nonpolar compounds that are, in turn, insoluble in water. They have broad biological function and structure. In addition, they are the primary source of stored energy in many organisms. Phospholipids and sterols are major structural elements of biological membranes. In addition, other lipid classes play fundamental roles as enzyme cofactors, electron carriers, emulsifying agents in the digestive tract, hormones, and intracellular messengers.

Fats in living organisms are derivatives of fatty acids and serve as a storage form of energy and essential fatty acids. Fatty acids consist of straight chain carbon atoms, with hydrogen atoms along the length of the chain. They have two ends; the carboxylic acid $(\mathrm{COOH})$ group is on one end (alpha) and other end of the molecule (omega) has a methyl (CH3) group. The hydrocarbon chain in fatty acids could vary from 4 to 36 carbons ( $\mathrm{C} 4$ to $\mathrm{C} 36$ ). This chain could be straight without any branch and become saturated or it could have branches along it and become unsaturated (Nelson and Cox, 2013). Melting point, as previously discussed, is directly influenced by the degree of molecule saturation and conformation. In saturated fatty acids, each carbon bond has free rotation that gives a flexibility to the hydrocarbon chain. Therefore, these fats can pack tightly. In contrast, unsaturated fatty acids, which have a double bond in their hydrocarbon chain, 
cannot pack together tightly, and their interactions with each other are therefore weaker. Therefore, less energy is needed to breakdown these links and they have a lower melting point compared to saturated fats (Nelson and Cox, 2013).

Two primary polyunsaturated fatty acids [PUFA] in fish are Docosahexaenoic acid [DHA] and Eicosapentaenoic acid [EPA] (Swanson, 2012). Fish-derived omega-3 fatty acids, EPA and DHA, are needed for normal fetal development, and they affect cardiovascular function and predisposition to Alzheimer's disease. However, because our bodies do not efficiently produce these fatty acids, some omega-3 fatty acids are needed from outside sources (Swanson, 2012).

Fatty acid synthesis occurs in the cytoplasm of cells. Biosynthesis requires the participation of a three-carbon intermediate, malonyl-CoA. The formation of malonyl-CoA from acetyl-CoA is an irreversible process that is catalyzed by acetyl-CoA carboxylase. Malonyl-CoA donates two carbons to an activated acyl group. When the chain length reaches 16 carbons, that product (palmitate, 16:0) leaves the cycle. Net products of fatty acids synthesis are, one molecule of palmitate, fourteen $\mathrm{NADP}^{+}$, six molecules of water, and eight COASH (Ohlrogge, 1997).

Mitochondrial oxidation of fatty acids takes place in three stages. In the first stage- $\beta$ oxidation-the fatty acids undergo oxidative removal of successive two-carbon units in the form of acetyl-CoA, starting from the carboxyl end of the fatty acyl chain. In the second stage of fatty acid oxidation the acetyl residues of acetyl-CoA are oxidized to $\mathrm{CO}_{2}$ via the citric acid cycle, which also takes place in the mitochondrial matrix. The first two stages of fatty acid oxidation produce the reduced electron carriers NADH and $\mathrm{FADH}_{2}$, which in the third stage donate electrons to the mitochondrial respiratory chain, through which the electrons are carried to oxygen.

Oxidation of fatty acids is an energy-yielding pathway in many organisms and tissues. During fatty acid oxidation, electrons are removed from fatty acids and pass through the respiratory 
chain, driving ATP synthesis; acetyl-CoA, produced from fatty acids may be completely oxidized to $\mathrm{CO}_{2}$ in the citric acid cycle, resulting in further energy conservation. The biological role of fatty acid oxidation differs from organism to organism, but the mechanism is the same.

The enzymes of fatty acid oxidation in animal cells are in the mitochondrial matrix. Fatty acids with chain lengths of 12 or fewer carbons enter mitochondria without the help of membrane transporters. In contrast, fatty acids with chain lengths of 14 or greater cannot pass directly through the mitochondrial membranes and undergo the three enzymatic reactions in the carnitine shuttle. During $\beta$-oxidation and cleavage of 2 -carbon units from the fatty acid chain, acetyl-CoA is generated and enters the citric acid cycle. Reduced cofactors, $\mathrm{NADH}$ and $\mathrm{FADH}_{2}$, are subsequently produced from the citric acid cycle. Oxygen is the final electron acceptor in the electron transport chain, regenerating oxidized cofactors, $\mathrm{NAD}^{+}$and $\mathrm{FAD}^{+}$. There is a four-protein complex in the electron transport chain that is involved in moving electrons from $\mathrm{NADH}$ and $\mathrm{FADH}_{2}$ to oxygen. A hydrogen ion gradient is established by pumping four hydrogen ions across the membrane from the matrix into the intermembrane space, producing ATP (Nelson et al. 2008)

Carbohydrate, fat, or protein ingested in excess of energy needs are stored as triglycerides that can be mobilized for energy later, enabling the body to withstand periods of nutrient deprivation. During lipolysis, $75 \%$ of all fatty acids are released and reesterified to form triacylglycerols.

Ingested triacylglycerols are insoluble macroscopic fat particles that, before they can be absorbed through the intestinal wall, must be converted to microscopic micelles; bile salts facilitate this step. Bile salts are synthesized from cholesterol in the liver and stored in the gallbladder; they are released into the small intestine after ingestion of a fatty meal. 
Lipid droplets, stored in the adipocytes, are mobilized for use elsewhere in the body by lipolytic enzymes. These lipases hydrolyze triglycerides into their glycerol and fatty acid components until only glycerol remains, and this breakdown requires three enzymatic reactions. Adipose triglyceride lipase (ATGL) modulates a first and rate limiting step of lipolysis. During this step, triacylglycerol is converted to diacylglycerol and a free fatty acid; this free fatty acid can then enter the bloodstream. Hormone sensitive lipase (HSL) removes another fatty acid, converting diacylglycerol to monoacylglycerol. In the end, monoacylglycerol lipase (MGL) will generate glycerol and the remaining fatty acid (Yamaguchi et al. 2007). 


\section{Materials and Methods}

\subsection{Animal care}

Rainbow trout were hatched in June 2015 and reared at the National Center for Cool and Cold Water Aquaculture. The first set of fish was sampled as a baseline when they were 6 months old before the experimental diet began on December 2015.

A constant 24-h photoperiod was provided, and feed was administered every alternate hour using automated feeders (T-drum 2000CE; Arvo-Tec, Fin-land). Water temperatures ranged from 12.4 to $14.0^{\circ} \mathrm{C}$. Fish were maintained indoors, under simulated ambient photoperiod.

\subsection{Fish sampling protocols}

Rainbow Trout from each tank were selectively sampled and sequentially euthanized with an overdose (200 mg/L) of tricaine methane sulfonate (MS-222; Western Chemical, Ferndale, Washington). Fish were individually brought to a team of researchers; they measured the length and weight of fish, then the viscera was removed through a ventral, midline incision. Fish were butterfly filleted and the fillets were weighed. The measurements were taken for fillet thickness and ventral "belly-flap" thickness using digital microcalipers. To measure thickness, three location were considered along the length of the carcass, at approximately 5, 50, and 95 percent of the overall fillet or belly flap length (cranial to caudal).

\subsection{Experimental design}

Fish care and experimentation follow guidelines outlined by the US Department of Agriculture (USDA) and the National Center for Cool and Cold Water Aquaculture (NCCCWA; USDA Agricultural Research Service; Kernersville, WV, U.S.A.) Animal Care and Use Committee. These guidelines are consistent with standards found in the National Research Council 
Publication Guide for Care and Use of Laboratory Animals. Rainbow trout eggs were hatched at USDA National Center for Cool and Cold Water Aquaculture, and fish were reared at the Freshwater Institute, Shepherdstown, West Virginia until harvest at 9 and 11 months of age. Four families were selected based on their whole-body weights before the diet experiment began. The two fast-growing families had the heaviest average body weight and the two slow-growing families that had the lowest average body weight among other families. From each family 3 fish were fed a fish meal or fish meal free diet (Table 3; 3 fish-by-4 families-by-2diets). Treatment combinations were replicated three times with tank as the experimental unit. In this case, the smallest unit to which diet was applied was the circular tanks. Three fish from each tank-by-diet-by-family combination were randomly selected at two weight endpoint, 750 and 1000 grams. The average weight of fish at 9 and 11 months of age was 581.15 and 912.63 grams, respectively. This experiment was conducted in the context of a sub-subplot design. Diet was a whole plot factor with two levels; family is the subplot factor with four levels, and harvest endpoint is a sub-subplot factor with two levels.

Statistical analysis was done using JMP and SAS software (JMP ${ }^{\circledR}$, Version Pro 14.0, SAS Institute Inc., Cary, NC, Copyright $\mathbb{C}^{2015}$; SAS ${ }^{\circledR}$, Version 9.4, SAS Institute Inc., Cary, NC, Copyright (C2002-2012). ANOVA model reflecting the split-split plot was applied in PROC GLIMMIX of SAS with fixed effects of Diet, Family and Age and random effect of tank by diet and Kenward-Roger method for denominator degrees of freedom approximation. Differences among the treatment levels for main effects and interactions were detected by multiple comparisons with Tukey adjustment. Effects were considered significant at $\mathrm{P} \leq 0.05$. Data are presented at LS Means \pm SEM (standard error of the mean). 


\subsection{Fillet characteristics}

Average fillet thickness was calculated following measurement with digital calipers at three standardized location; just cranial to the pectoral fin, just caudal to the pelvic fin, and at the vent. Separable muscle yield is boneless skinless fillet calculated as a percent of Whole-Body Weight (WBW). Separable muscle is boneless, skinless fillet following removal of the pectoral girdle, vertebral column and associated ribs, belly flap with pectoral fins, and the skin.

To record the fillet surface color, a chromameter (Minolta, Model CR-300; Minolta Camera Co., Osaka, Japan) was used. This instrument was color calibrated using a standard white plate No. 21333180 (CIE Y 93.1; x0.3161; y0.3326), and lightness, redness, and yellowness values were recorded at three locations above the lateral line along the long axis of the right fillet.

To analyze the texture, fillet cut into $440 \mathrm{X} 80 \mathrm{~mm}$ sections and were cooked in a microprocessor-controlled smoke oven (Model CVU-490; Enviro-Pak, Clackamas, OR, U.S.A.) at $82{ }^{\circ} \mathrm{C}$. The cooking process was stopped when the internal fillet temperature reached $65.5^{\circ} \mathrm{C}$. This cooking temperature was selected according to U.S. Department of Agriculture (USDA) recommended, minimum internal temperature (Nilsson and Ek-strand 1995) for fish to achieve a safe temperature without overcooking. After 45 minutes of cooking, samples were cooled at room temperature. Cook loss was calculated as the percent loss between raw and cooked samples.

To measure the instrumental texture, texture of raw and cooked fillet sections was measured at room temperature $\left(25^{\circ} \mathrm{C}\right)$ using a 5-blade, Allo-Kramer $(\mathrm{AK})$ shear attachment mounted to the TA-HDi ${ }^{\circledR}$ Texture Analyzer (Texture Technologies Corp., Scarsdale, N.Y., U.S.A.), equipped with a 50-kg load cell, at a crosshead speed of $127 \mathrm{~mm} / \mathrm{min}$. Force-deformation graphs were recorded and analyzed using the Texture Expert Exceed software (version 2.60; Stable Micro Systems Ltd., Surrey, U.K.). To determine the shear force, muscle fiber sections were 
sheared perpendicular to the long axis of the fillet. Force-deformation graphs were recorded and analyzed using the Texture Expert Exceed software (version 2.60; Stable Micro Systems Ltd., Surrey, U.K.).

Moisture, crude fat, crude protein, and ash content were determined for muscle samples. All procedures followed AOAC approved methods (AOAC, 1990). For estimation of moisture content, aluminum pans were weighed using the analytical balance. One to two grams of sample were placed into each pan and placed in the drying oven overnight at $110{ }^{\circ} \mathrm{C}$. Moisture content was calculated by difference based on weight of cooled pans with dried samples. Crude fat content was determined for muscle. All procedures followed the Soxhlet indirect method; 1 - $1.5 \mathrm{~g}$ sample was weighed using an analytical balance, and these samples were wrapped in Whatman \# 41 filter paper. Samples were placed in a Soxhlet extractor between 18 and 24 hours. Following extraction, samples were dried overnight in a $110{ }^{\circ} \mathrm{C}$ drying oven and reweighted. Crude protein was calculated using Kjeltec ${ }^{\mathrm{TM}} 2300$ (Foss North America; Eden Prairie, Minnesota, U.S.A.). Approximately 0.3 -gram sample and copper-sulfate tablets used as a catalyst, were dissolved in $10 \mathrm{ml}$ of sulfuric acid. Samples were placed in a $400{ }^{\circ} \mathrm{C}$ heating block at 50 minutes for digestion. After cooling, $25 \mathrm{~mL}$ of distilled water was added with swirling and heating to re-suspend solids. Tubes containing the solutions were distilled and titrated on the Kjeltec distillation unit. Volume of acid required to titrate the samples was then considered to determine nitrogen content. Therefore, percent crude protein was calculated from percent nitrogen using 6.25 as the conversion factor.

To determine ash content, 1-3 grams of sample were placed in a crucible and kept in an ashing oven overnight at $550^{\circ} \mathrm{C}$. After cooling, the difference in weight between initial and ashed sample was used to calculate percent ash. 


\subsection{Fatty acid analysis}

Lipid extraction and fatty acid methylation are complete.

\subsubsection{Lipid extraction:}

The lipid extraction was accomplished by Bligh and Dyer (1959) procedures using a chloroform-methanol (C: M) mixture. For lipid extraction, 0.5 gram of powdered muscle was used. In the next step, $5 \mathrm{ml}$ Trizma/EDTA buffer was used to adjust to $\mathrm{pH}=7.4$, and $20 \mathrm{ml} \mathrm{C}$ : M: A (chloroform: absolute methanol: glacial acetic acid (C: M:A); 400:200:3mL) were added. Tubes were hold at room temperature for 10 minutes. The mixture was centrifuged at 900x g (4000 rpm) for 10 minutes at $10{ }^{\circ} \mathrm{C}$. The lower layer was filtered through a 1-PS filter (filter paper was pre-

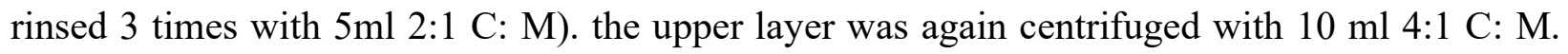
The lower layer again filtered through a 1-PS filter. All filtered samples were collected and dried under nitrogen gas at $60{ }^{\circ} \mathrm{C}$ in a heating block.

\subsubsection{Methylation:}

Extracted lipids were methylated using the method Fritshe and Johnston (1990).

Four $\mathrm{ml}$ of $4 \% \mathrm{H}_{2} \mathrm{SO}_{4}$ solution were added to the extracted samples and a test tube rack of extracted samples was incubated in a water bath at $90{ }^{\circ} \mathrm{C}$ for 60 minutes. Samples were cooled at room temperature, and $3 \mathrm{ml}$ of deionized/distilled water were added to stop the reaction. Samples were extracted with $8 \mathrm{~mL}$ chloroform and centrifuged at $900 \mathrm{x} \mathrm{g}(4000 \mathrm{rpm})$ and $10{ }^{\circ} \mathrm{C}$ for 10 minutes. The bottom layer (chloroform layer) was transferred through a $\mathrm{Na}_{2} \mathrm{SO}_{4}$ filled pipette into a $10 \mathrm{~mL}$ glass tube. 
The pipette was rinsed again with a half pipette of chloroform. Extracted samples were dried under nitrogen gas in $60{ }^{\circ} \mathrm{C}$ heating block. The dried sample was re-suspended in $3 \mathrm{~mL}$ of filtered isooctane and stored at $-20^{\circ} \mathrm{C}$ until gas chromatography (GC) analysis.

1.10.3 Fatty acid separation and quantification:

Fatty acid analyses were not complete at the time of thesis preparation due to GC malfunction. Nonetheless, these data will be generated for inclusion in resulting manuscript. 


\section{Results and discussion}

Butterfly Fillet Yields. Percent butterfly fillet for fish on the FMF diet was greater (adjusted P-value $=0.02$ ) than for fish on the FM diet. Pairwise-comparisons of LS Means among four families indicate that trout from families 40,102 and 159 had higher percent butterfly weights than family 187 (adjusted P-value $=0.01,0.03$, and 0.002 , respectively). Rainbow trout at 9 and 11 months did not respond similarly within each family $(40,102,159$ and 187$)$ for percent butterfly fillet $(\mathrm{P}<0.05)$. Pairwise-comparisons of LS Means among four families and two ages indicate that fish from families 102 and 159 at 9 months had higher percent butterfly weight than fish from family 187 at the same age (Adj $p=0.018$ and 0.0108 , respectively). Nine-month old fish from family 159 also had higher butterfly yields than fish from 187 at 11 -month-old (Adj. p=0.03)

(Figure 1). The main effect of age, diet, family, and their interactions did not affect separable muscle as a percent of whole-body weight $(\mathrm{P}>0.05)$.

Butterfly fillet yields for fish fed FM and FMF diets were $69.92 \pm 0.29$ and $71.45 \pm 0.3$, respectively. From a production and economic perspective, a FMF diet could replace a FM diet without any negative effect on butterfly weight. Barrows and Frost (2014) reported that diets containing blends of pistachio and almond meal with only 5\% fishmeal resulted in comparable rainbow trout growth compared to a standard fishmeal-based diet ( Barrows and Frost, 2014). Liland (2015) also indicated that inclusion of poultry meal and porcine blood meal in Atlantic salmon diets can result in health benefits such as reduced liver triacylglycerols and a trend towards improved gut health (Liland et al., 2015) without compromising growth.

Percent separable muscle was not affected by diet, age, and family. In addition, the interaction of each of the main effects was not significant. 
In a significant diet-by-family interaction, fish from family 159 , fed the FM diet, had thicker fillets than fish from families 102, 159, and 187 which were fed the FMF diet, and family 102, fed with FM diet (adjusted P-value $=0.02,0.01,0.003$, and 0.02, respectively) (Figure 2). Trout fillets at 9 months were thicker than at 11 months $(16.89 \pm 0.28 \mathrm{v}, 15.06 \pm 0.28 \mathrm{~mm}$, respectively). Pairwise-comparisons of LS Means indicated that belly flap thickness increased as age of trout increased from 9 to 11 months old, $0.85 \pm 0.02$ and $1.07 \pm 0.02$, respectively (adjusted P-value <.0001). Trout fed the FM diet had thicker belly flaps than trout fed the FMF diet (adjusted P-value $=0.02$ ). Davidson et al. (2014) reported that fillet thickness was positively correlated with age, and their findings are in agreement with our results.

Compositional Analyses. Few, separable muscle composition differences were associated with treatment variables (Table 1). Ash content was unaffected $(\mathrm{P}>0.05)$ by diet, age, and family. Percent crude protein was higher in fish at 11 (adjusted p-value $=0.01$ ) than 9 months. Trout fed the FM diet had higher fat and lower moisture levels compared to those that were fed the FMF diet (adjusted p-value $=0.001$ and 0.01 , respectively); these components of muscle proximate composition are inversely related. Pairwise-comparisons of LS Means among families indicate that trout from families 102 and 159 have a higher amount of fat than family 187 (adjusted pvalue $=0.001$ and 0.008 , respectively). And, as we expected the intramuscular moisture in trout from family 187 were much higher compared to families 102 and 159 (adjusted $p$-value $=0.004$ and 0.02 , respectively). Various studies on different types of fish reached a similar conclusion; fish with relatively low moisture content had high lipid content. (Palmeri et al., 2007). Palmeri (2007) also reported that muscle protein content was inversely proportional to lipid content across fillet portions in all fish species. These results support our findings; trout from family 102 were higher in fat content and had the lowest amount of protein compared to other families. 
Cook yield was affected by diet and family $(\mathrm{P}<0.05)$. Pairwise-comparisons of LS Means among four families indicate that boneless, skinless trout fillets from family 159 had higher percent cook yield than family 40,102 , and 187 (adjusted p-value $=0.001,0.0001$, and 0.001 , respectively). Fish fed the FM diet have a higher percent cook yield (adjusted p-value=0.002). Typically, greater cook yield indicates increased water and fat retention. It is expected that increased fillet thickness would slow cooking rate and contribute to greater cook yield. Family 159 fillets exhibited the highest cook yield and these fillets were also thicker compared to other families. In addition, among the four families, 102 trout had highest percent intramuscular fat and therefore, reduced cooked yield from other families. These results agree with Davidson et al. (2014) who evaluated fillet quality of rainbow trout and arrived at the same conclusions regarding cook yield of rainbow trout (Davidson et al., 2014).

$\underline{\text { Texture. }}$ Cooked fillet shear force at 9 and 11 months did not respond similarly within each family $(40,102,159$ and 187) for Allow-Kramer shear force. Pairwise-comparisons of LS Means indicate that families 102 and 187 trout, at 11 months, had a higher shear force than family 40 trout at 11 month and family 159 trout at 9 months (Figure 3).

Diet, family, and age had a significant effect on raw fillet Allo-Kramer shear force. Pairwise-comparisons of LS Means among four families revealed that raw fillets from families 40 and 187 were firmer than family 159 (adjusted $p$-value $=0.02$ and 0.001 , respectively). Raw shear force of fish on the FMF diet was higher than fish on FM diet (adjusted P-value=0.04). Likewise, raw fillet shear force in fish at 9 months old was higher (adjusted P-value $=0.003$ ) than at 11 months.

Shear force is a reliable assessment of fish fillet firmness. In the current study, shear force of muscle increased when fish were fed the FMF diet compared to the FM diet. An increase in 
cooked fillet firmness was due to denaturation of muscle fibers and water loss (Schubring 2008). During cooking, due to the water evaporation, shear force value increased among four family. Increased energy of shear for cooked fillets suggested that they were more extensible than their raw state. Heat induces several chemical and physical changes associated with muscle fiber and connective tissue proteins, and as a result of these chemical and physical changes, water-holding capacity is reduced in 2 phases (Hamm 1977). Between 30 and $50^{\circ} \mathrm{C}$, coagulation of myofibrillar proteins takes place, and the largest decrease in water-binding capacity is observed. From 55 to $90^{\circ} \mathrm{C}$, shrinkage of the connective tissue network and increased interaction of the coagulated actomyosin system cause smaller amounts of water to escape. These results are similar to the results from other studies (Aussanasuwannakul et al., 2010) who showed that cooked fillets of rainbow trout have higher shear force. Typically, there is a highly correlations between tenderness and the fat content of the flesh. Based on our results, the average fat percent in trout fed the FM diet were higher than FMF diet. Therefore, we expected that the shear force be higher in fish that consumed a FMF diet, since the fat content was lower in their diet.

Diet, family, and age had a significant effect on raw and cooked energy of rainbow trout fillet $(\mathrm{P}<0.05)$. Pairwise-comparisons of LS Means shows that cooked and raw energy from fish at 11 months old was around thirty five percent more for fish fillets from animals at 9 months. (adjusted P-value $=0.0001$ and 0.0001 , respectively). Pairwise-comparisons of LS Means indicate that raw and cooked energy in trout that fed with FM diet were higher than trout that fed with FMF diet (adjusted p-value $=0.009$ and 0.0004 , respectively). Trout from families 40, 159, and $187 \mathrm{had}$ a higher cooked energy than family 102 (Table 2; adjusted P-value $=0.02,0.006$, and 0.001 , respectively). In addition, energy in raw trout from family 40 and 187 was higher than family 102 (Table 2; adjusted $p$-value $=0.04$ and 0.004 , respectively). 
$\underline{\text { Color. }}$ Yellow-to-blue color value of fillets ( $\left.\mathrm{b}^{*}\right)$ was not affected by diet, age, and family $(\mathrm{P}>0.05)$. Pairwise-comparisons of LS Means among families reveal that trout from family 187 have a higher red-to-green color $\left(\mathrm{a}^{*}\right)$ value than family 159 (adjusted $\mathrm{p}$-value $\left.=0.004\right)$. The $\mathrm{a}^{*}$ value color of fish on the FM diet was higher (adjusted $\mathrm{p}$-value $=0.01$ ). In addition, $\mathrm{a}^{*}$ value color was higher for fish at 11 months old (adjusted p-value $=0.02$ ).

Pairwise-comparisons of LS Means indicate that lightness ( $\left.\mathrm{L}^{*}\right)$ value in fish from family 40 and fed the FMF diet (Figure 4) was higher than fish from 187 and 40 that were on the FM diet (adjusted P-value $=0.01$ and 0.04 , respectively).

The $\mathrm{a}^{*}$ value of fillets was higher for trout fed the FM diet, indicating the greater degree of redness. Our results agree with a previous study that indicated, as the age of fish increased the redness of the fillet tended to increase (Moon et al., 2006). Fillet color is an important quality attribute that consumers differentiate. Davidson (2018) indicated that $a^{*}$ value was higher for Salmon, Salmo salar, fed the FMF diet, which supports our findings. In addition, results from current study agree with Moon et al (2006), who found that there is no relationship between age and lightness of meat.

Head-on-gutted fish from the FM diet were heavier (Figure 5; adjusted p-value=0.005), and this observation is consistent with results of a study that was done with Atlantic salmon that were on FM diet (Davidson et al., 2018). Pairwise-comparisons of LS Means among four families indicate that trout from families 40,159, and 187 have a higher head-on-gutted percent than fish from family 102 (adjusted p-value $=0.0009,0.0001$, and 0.022, respectively) (Figure 5). Head-ongutted weight of trout at 11 months old was thirty eight percent heavier than 9-month-old fish (adjusted P-value < 0.0001). 


\section{Summary and conclusions}

In this study, fish from four families were fed a fish meal or fish meal free diet, and they were harvested at 9 and 11 months of age. Type 3 Tests of Fixed Effects of diet, family, and age were implemented on response variables that were related to weight and quality attributes of fillet to analyze the significance of the effect of family, age, diet, and their interactions. The fishmeal free diet did not negatively affect butterfly fillet yield as a percent of whole-body weight. A familyby-diet interaction was observed for fillet thickness. Diet and family affected fat and moisture percent. In addition, protein percent of fillet was affected by age of trout. Trout fed the FM diet had higher fat and lower moisture levels compared to those that were fed the FMF diet. Diet and family had a significant effect on cook yield of fillet as a product attribute. Cook yield in 159 trout was greater than for other families. Moreover, head-on-gutted (HOG) percent as a product yield of rainbow trout fillet was affected by diet, family, age, and the interaction of family-by-age. Headon-gutted fish from the FM diet were heavier. Also, Head-on-gutted weight of trout at 11 months old was thirty eight percent heavier than 9-month-old fish. Cooked fillet shear force was affected by the interaction of family-by-age. Family 102 and 187, at 11 months, had a higher shear force than 40 trout at 11 month and 159 trout at 9 months. Raw fillet shear force was affected by family, diet, and age. Raw fillets from families 40 and 187 were firmer than family 159. Also, Raw shear force of fish on the FMF diet was higher than fish on FM diet, and raw fillet shear force in fish at 9 months old was higher than at 11 months.

Diet, family, and age had a significant effect on raw and cooked energy of rainbow trout fillet. Degree of fillet redness $\left(a^{*}\right)$ was affected by diet of trout, trout that fed FM diet indicating the greater degree of redness. Additionally, trout from family 187 have a higher $\left(\mathrm{a}^{*}\right)$ value than family 159. Furthermore, the lightness $\left(L^{*}\right)$ value was affected by the interaction of diet-by- 
family. (L*) value in fish from family 40 and fed the FMF diet (Figure 4) was higher than fish from 187 and 40 that were on the FM diet.

The results of this study can be potentially useful for engineers and operators of industry when culturing rainbow trout under similar conditions. 


\section{Tables}

Table 1. Rainbow trout fillet composition as affected by diet, family and age (LS Means \pm Standard Error)

\begin{tabular}{lllllllll}
\hline \multicolumn{3}{c}{ Diet } & \multicolumn{5}{c}{ Family } \\
& FM & FMF & 40 & 102 & 159 & 187 & 9 & 11 \\
\hline Moisture & 67 & 68.81 & 68.10 & 67.05 & 67.47 & 69.01 & 68.20 & 67.62 \\
$(\%)$ & $\pm 0.29^{\mathrm{a}}$ & $\pm 0.29^{\mathrm{b}}$ & $\pm 0.37^{\mathrm{a}}$ & $\pm 0.39^{\mathrm{b}}$ & $\pm 0.37^{\mathrm{b}}$ & $\pm 0.37^{\mathrm{a}}$ & $\pm 0.27^{\mathrm{a}}$ & $\pm 0.28^{\mathrm{a}}$ \\
\hline Protein & 19.68 & 19.90 & 19.64 & 19.39 & 19.87 & 20.04 & 19.49 & 19.98 \\
$(\%)$ & $\pm 0.13^{\mathrm{a}}$ & $\pm 0.13^{\mathrm{a}}$ & $\pm 0.18^{\mathrm{a}}$ & $\pm 0.19^{\mathrm{a}}$ & $\pm 0.18^{\mathrm{a}}$ & $\pm 0.18^{\mathrm{a}}$ & $\pm 0.13^{\mathrm{a}}$ & $\pm 0.13^{\mathrm{b}}$ \\
\hline Fat (\%) & 13.91 & 12.2 & 12.58 & 14.37 & 13.81 & 11.47 & 13.10 & 13.02 \\
& $\pm 0.33^{\mathrm{a}}$ & $\pm 0.34^{\mathrm{b}}$ & $\pm 0.47^{\mathrm{ab}}$ & $\pm 0.5^{\mathrm{a}}$ & $\pm 0.47^{\mathrm{a}}$ & $\pm 0.47^{\mathrm{bc}}$ & $\pm 0.33^{\mathrm{a}}$ & $\pm 0.34^{\mathrm{a}}$ \\
\hline Ash (\%) & 1.34 & 1.39 & 1.39 & 1.27 & 1.34 & 1.45 & 1.39 & 1.34 \\
& $\pm 0.05^{\mathrm{a}}$ & $\pm 0.06^{\mathrm{a}}$ & $\pm 0.07^{\mathrm{a}}$ & $\pm 0.07^{\mathrm{a}}$ & $\pm 0.07^{\mathrm{a}}$ & $\pm 0.07^{\mathrm{a}}$ & $\pm 0.05^{\mathrm{a}}$ & $\pm 0.05^{\mathrm{a}}$ \\
\hline
\end{tabular}

$F M=$ fishmeal-based; $F M F=$ fishmeal-free

${ }^{a b}$ For each fillet characteristic different superscript letters indicate significant difference between or among the levels of the main effect.

Table 2.Energy yield for raw and cooked fillet of rainbow trout (LS Means \pm Standard Error)

\begin{tabular}{lllllllll}
\hline & \multicolumn{2}{c}{ Diet } & \multicolumn{4}{c}{ Family } & \multicolumn{3}{c}{ Age } \\
& FM & FMF & 40 & 102 & 159 & 187 & 9 & 11 \\
\hline Cooked & 64581 & 56325 & 61344 & 52555 & 63095 & 64818 & 47542 & 73365 \\
Energy & $\pm 1432^{\mathrm{a}}$ & $\pm 1476^{\mathrm{b}}$ & $\pm 2025^{\mathrm{ab}}$ & $\pm 2114^{\mathrm{bc}}$ & $\pm 2025^{\mathrm{a}}$ & $\pm 2025^{\mathrm{a}}$ & $\pm 1432^{\mathrm{a}}$ & $\pm 1476^{\mathrm{b}}$ \\
$\mathbf{( g / m m )}$ & & & & & & & & \\
\hline Raw & 55386 & 47327 & 54191 & 42616 & 50670 & 57951 & 41542 & 61172 \\
Energy & $\pm 2015^{\mathrm{a}}$ & $\pm 2077^{\mathrm{b}}$ & $\pm 285^{\mathrm{a}}$ & $\pm 3023^{\mathrm{bc}}$ & $\pm 285^{\mathrm{ab}}$ & $\pm 285^{\mathrm{a}}$ & $\pm 2015^{\mathrm{a}}$ & $\pm 2077^{\mathrm{b}}$ \\
$\mathbf{( g / m m )}$ & & & & & & & & \\
\hline
\end{tabular}

$\overline{{ }^{a b c} \text { For each fillet characteristic different superscript letters indicate significant difference between }}$ or among the levels of the main effect. 
Table 3. formulation of the test (zero fishmeal/ low phosphorus) diet and the control (fish meal) diet

\begin{tabular}{|c|c|c|}
\hline Ingredient & Commercial & Alternative \\
\hline Fish meal ${ }^{\text {a }}$ & 8.00 & -- \\
\hline $\begin{array}{l}\text { Barley protein concentrate } \\
\text { b }\end{array}$ & -- & 29.40 \\
\hline Poultry meal $^{c}$ & 16.60 & 22.80 \\
\hline Soybean meal ${ }^{\mathrm{d}}$ & 13.38 & -- \\
\hline Soy protein concentrate $e^{e}$ & 8.75 & -- \\
\hline Corn protein concentrate ${ }^{f}$ & 4.53 & -- \\
\hline Blood meal $\mathrm{g}$ & 5.59 & -- \\
\hline Mixed nut meal ${ }^{h}$ & -- & 8.70 \\
\hline Wheat flour i & 21.19 & 16.55 \\
\hline Fish oil ${ }^{j}$ & 16.40 & -- \\
\hline Fish trimmings oil ${ }^{\mathrm{k}}$ & -- & 14.52 \\
\hline Lysine HCl & 1.36 & 1.30 \\
\hline Methionine & 0.58 & 0.45 \\
\hline Threonine & 0.52 & 0.22 \\
\hline Taurine & -- & 0.50 \\
\hline Dicalcium phosphate & 1.20 & 2.26 \\
\hline Vitamin premix $^{1}$ & 1.00 & 1.00 \\
\hline Choline CL & 0.60 & 0.60 \\
\hline Vitamin $^{\mathbf{C}^{\mathrm{m}}}$ & 0.20 & 0.20 \\
\hline Trace min premix ${ }^{n}$ & 0.10 & 0.10 \\
\hline Sodium chloride ${ }^{0}$ & -- & 0.28 \\
\hline Potassium chloride $^{0}$ & -- & 0.56 \\
\hline Magnesium oxide $^{0}$ & -- & 0.05 \\
\hline \multicolumn{3}{|c|}{ Calculated composition, as-is basis } \\
\hline Crude Protein, \% & 40.0 & 40.0 \\
\hline Lipid, \% & 20.0 & 20.0 \\
\hline Phosphorus, \% & 0.91 & 0.92 \\
\hline
\end{tabular}


${ }^{a}$ Menhaden Special Select, Omega Proteins Corp, $610 \mathrm{~g} / \mathrm{kg}$ crude protein

${ }^{b}$ Montana Microbial Products, $521 \mathrm{~g} / \mathrm{kg}$ crude protein

${ }^{c}$ IDF Inc., $832 \mathrm{~g} / \mathrm{kg}$ protein

${ }^{d}$ Archer Daniels Midland Company, $472 \mathrm{~g} / \mathrm{kg}$ protein

${ }^{e}$ Hamlet Protein, HP-300, $560 \mathrm{~g} / \mathrm{kg}$ crude protein

${ }^{f}$ Cargill, Empyreal 75, $756 \mathrm{~g} / \mathrm{kg}$ crude protein

${ }^{g}$ Wilbur-Ellis, $892 \mathrm{~g} / \mathrm{kg}$ crude protein

${ }^{h}$ Adaptive Bio-Resources, $546 \mathrm{~g} / \mathrm{kg}$ crude protein

${ }^{i}$ Manildra Milling, $120 \mathrm{~g} / \mathrm{kg}$ protein

${ }^{j}$ Omega Proteins Inc., Virginia Prime menhaden oil

${ }^{k}$ BioOregon Protein Inc., North Pacific whitefish trimmings oil

${ }^{l}$ DSM Nutritional Products ARS 702; contributed, per $\mathrm{kg}$ diet; vitamin A $9650 \mathrm{IU}$; vitamin D $6600 \mathrm{IU}$; vitamin E $132 \mathrm{IU}$; vitamin $\mathrm{K3} 1.1 \mathrm{gm}$ : thiamin mononitrate $9.1 \mathrm{mg}$; riboflavin $9.6 \mathrm{mg}$; pyridoxine hydrochloride $13.7 \mathrm{mg}$; pantothenate DL-calcium $46.5 \mathrm{mg}$; cyancobalamin $0.03 \mathrm{mg}$; nicotinic acid $21.8 \mathrm{mg}$; biotin $0.34 \mathrm{mg}$; folic acid $2.5 \mathrm{mg}$; inostitol $600 \mathrm{mg}$.

${ }^{m}$ Stay-C, 35\%, DSM Nutritional Products

${ }^{n}$ Sigma-Aldrich Company, ARS 640, contributed in $\mathrm{mg} / \mathrm{kg}$ of diet; manganese 13; iodine 5; copper 9; zinc 40.

${ }^{\circ}$ Sigma-Aldrich Company 


\section{Figures}

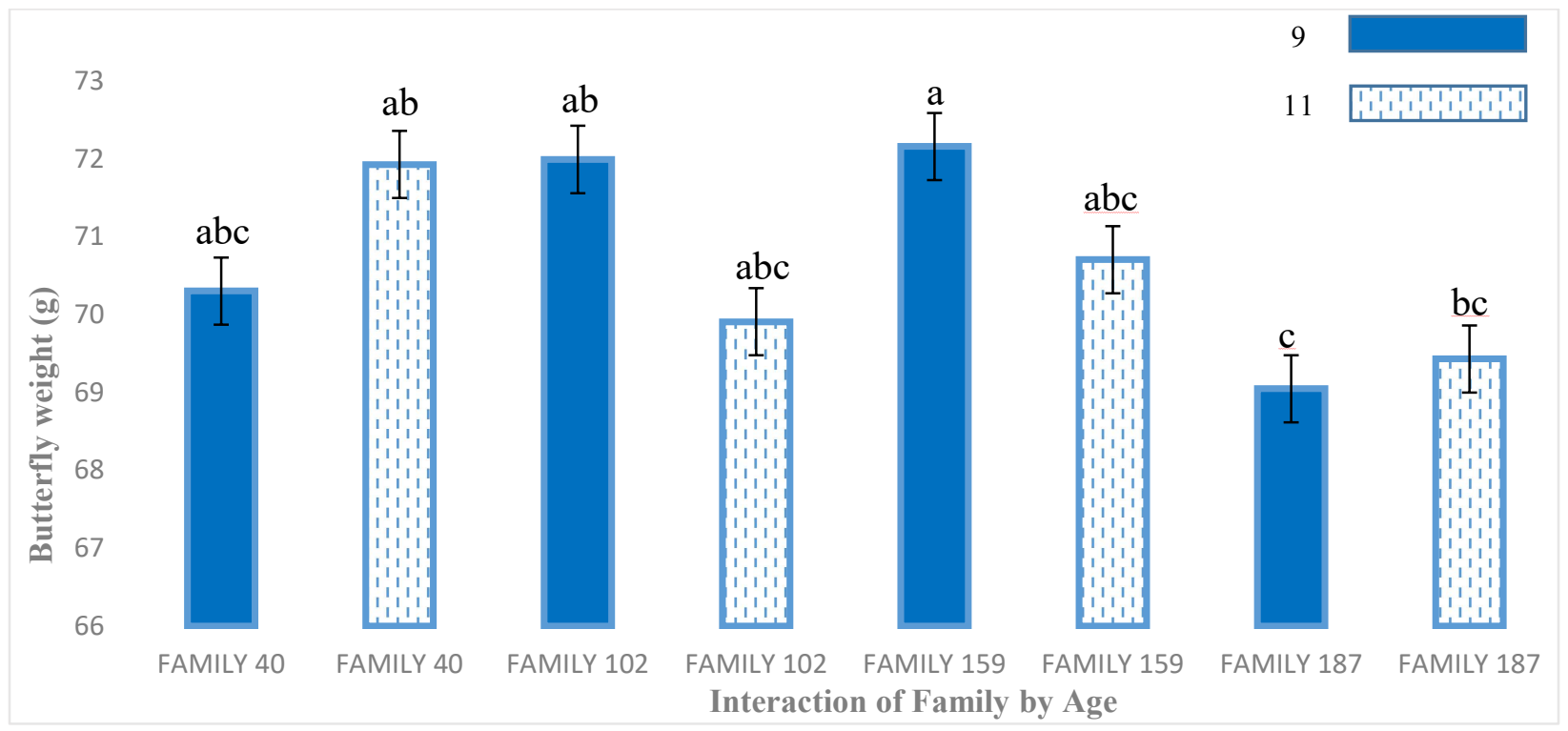

Figure 1. Effect of Family-by-Age Interaction (LS Means) on butterfly fillet as a percent of whole-body weight

${ }^{a b c}$ For each fillet characteristic different superscript letters indicate significant difference between or among the levels of the main effect.

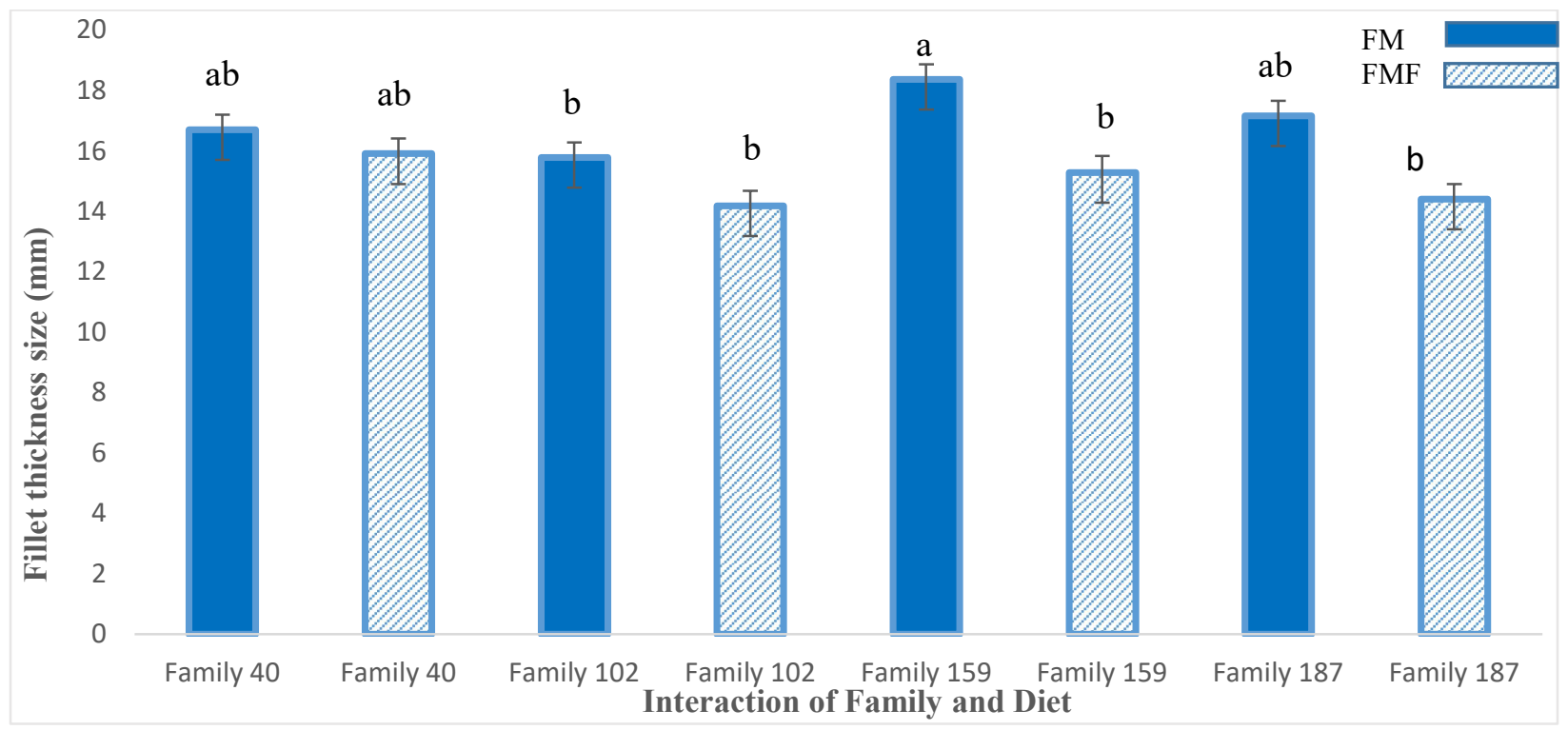

Figure 2.Effect of Diet-by-Family Interaction (LS Means) on fillet thickness size of rainbow trout

${ }^{\mathrm{ab}}$ For each fillet characteristic different superscript letters indicate significant difference between or among the levels of the main effect. 


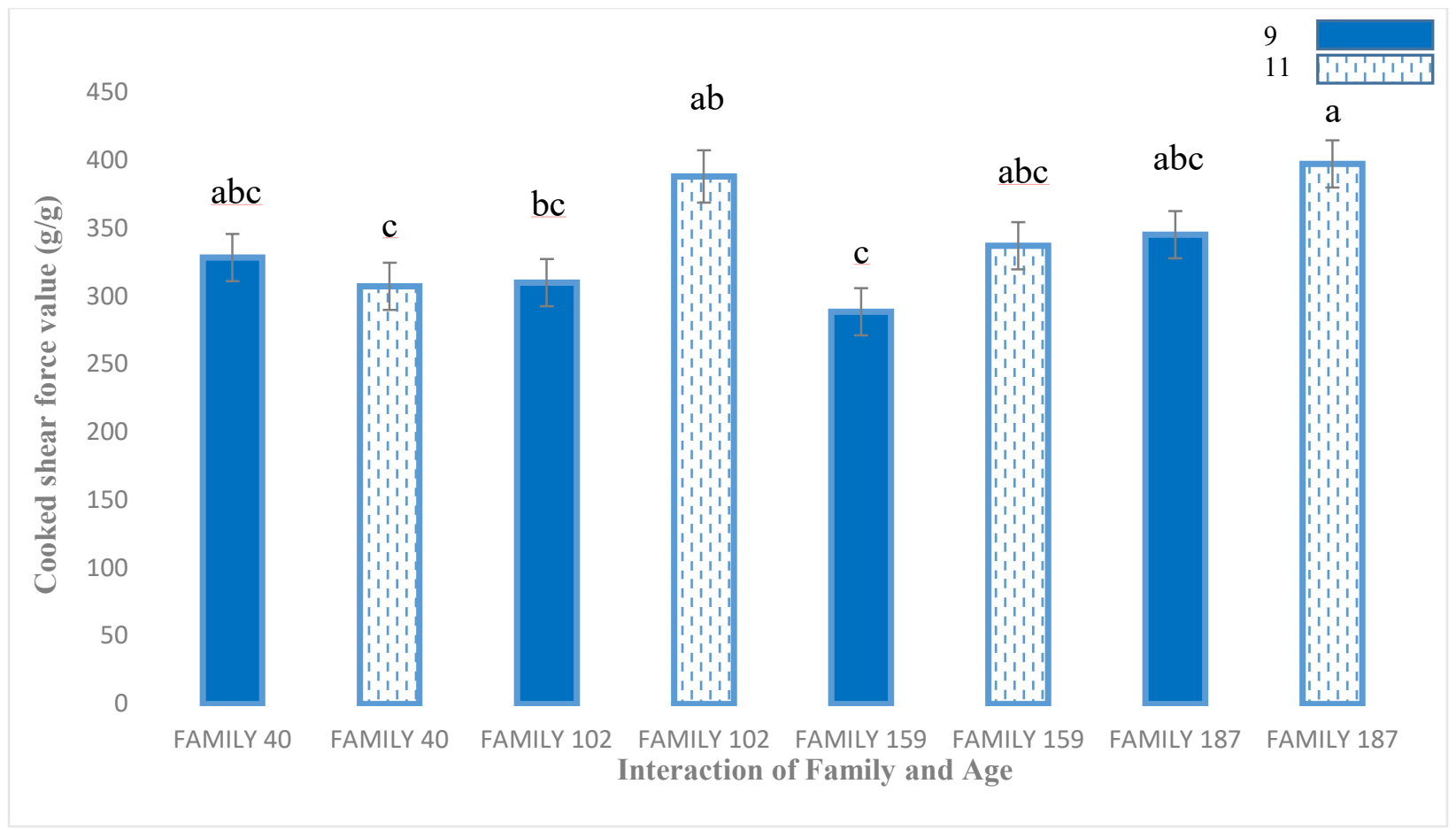

Figure 3.Effect of Family-by-Age interaction (LS Means) on cooked shear force value of rainbow trout

${ }^{\mathrm{abc}}$ For each fillet characteristic different superscript letters indicate significant difference between or among the levels of the main effect.

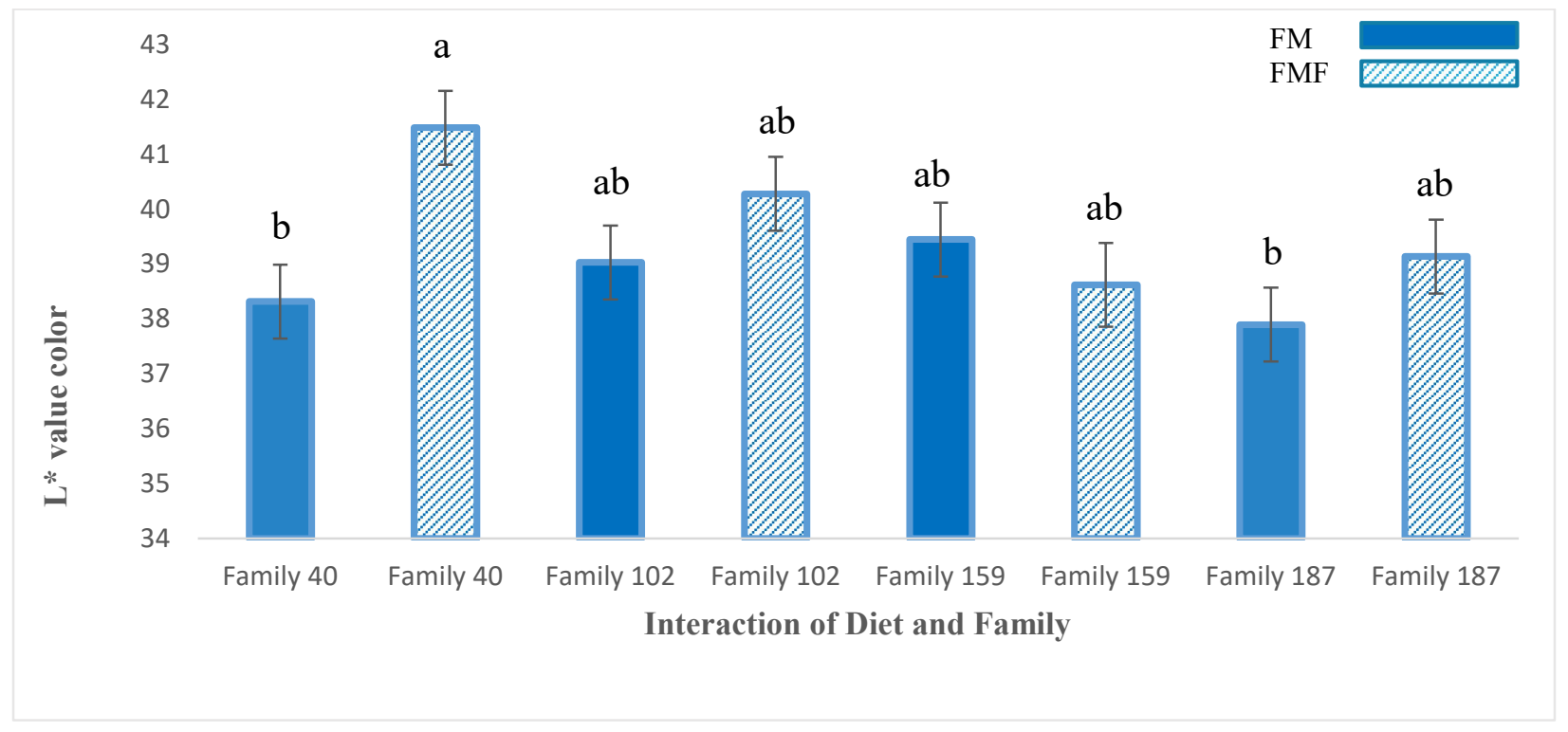

Figure 4.Effect of Diet-by-Family interaction (LS Means) on lightness ( $\left.L^{*}\right)$ value color of rainbow trout

${ }^{a b}$ For each fillet characteristic different superscript letters indicate significant difference between or among the levels of the main effect. 


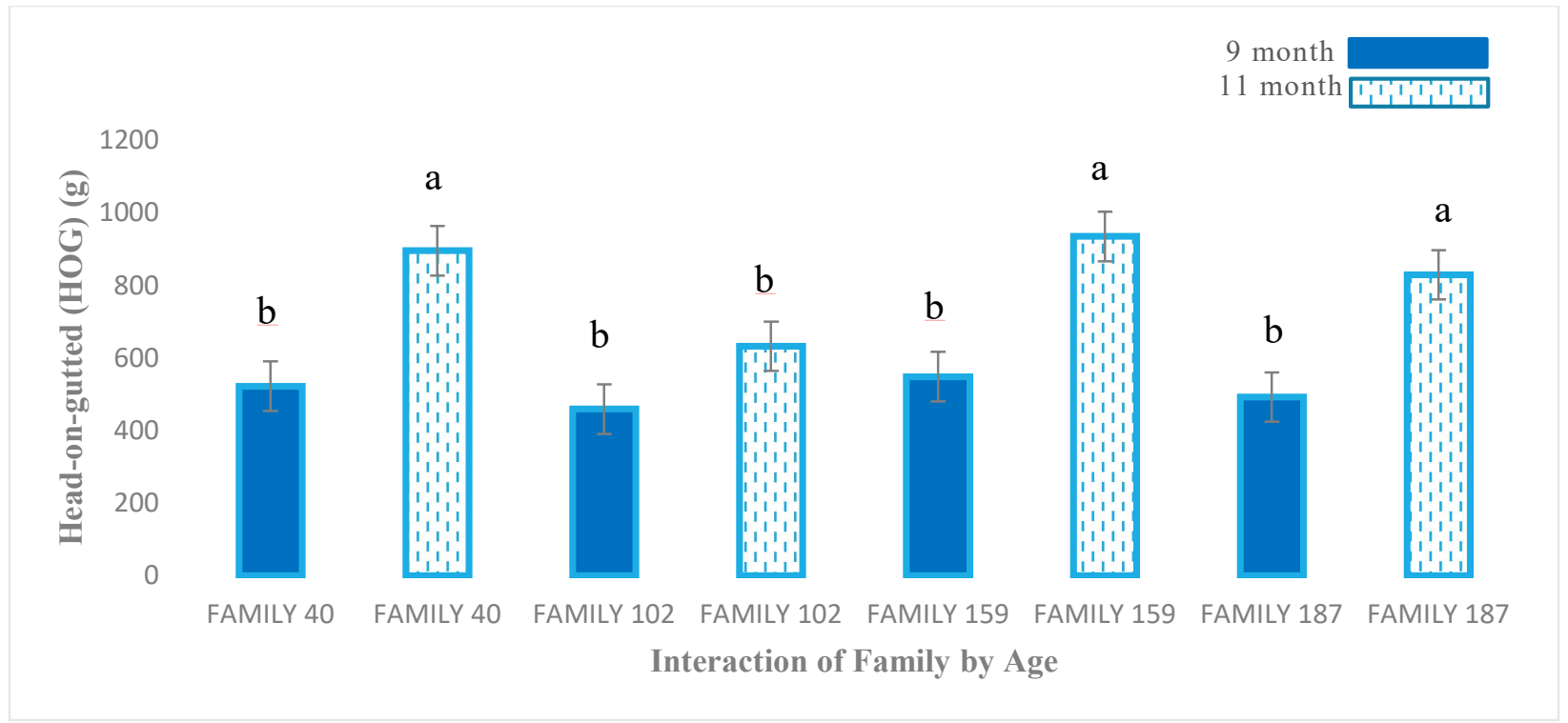

Figure 5.Effect of Family-by-Age interaction on head-on-gutted percent of rainbow trout (LS Means)

${ }^{a b}$ For each fillet characteristic different superscript letters indicate significant difference between or among the levels of the main effect. 


\section{References:}

Aussanasuwannakul A, Kenney PB, Weber GM, Yao J, Slider SD, Manor ML, Salem M (2011) Effect of sexual maturation on growth, fillet composition, and texture of female rainbow trout (Oncorhynchus mykiss) on a high nutritional plane. Aquaculture 317:79-88

Aussanasuwannakul, A., Kenney, P. B., Brannan, R. G., Slider, S. D., Salem, M., \& Yao, J. (2010). Relating instrumental texture, determined by variable-blade and Allo-Kramer shear attachments, to sensory analysis of rainbow trout, Oncorhynchus mykiss, fillets. Journal of food science, 75(7), S365-S374

Bairagi, A., Sarkar Ghosh, K., Sen, S. K., \& Ray, A. K. (2004). Evaluation of the nutritive value of Leucaena leucocephala leaf meal, inoculated with fish intestinal bacteria Bacillus subtilis and Bacillus circulans in formulated diets for rohu, Labeo rohita (Hamilton) fingerlings. Aquaculture Research, 35(5), 436-446

Barrows, F. T., \& Frost, J. B. (2014). Evaluation of the nutritional quality of co-products from the nut industry, algae and an invertebrate meal for rainbow trout, Oncorhynchus mykiss. Aquaculture, 434, 315-324

Barrows, F. T., Gaylord, T. G., Stone, D. A. J., \& Smith, C. E. (2007). Effect of protein source and nutrient density on growth efficiency, histology and plasma amino acid concentration of rainbow trout (Oncorhynchus mykiss Walbaum). Aquaculture Research, 38(16), 1747-1758

Bjerkeng B, Refstie S, Fjalestad KT, Storebakken T, Rødbotten M, Roem AJ (1997) Quality parameters of the flesh of Atlantic salmon (Salmo salar) as affected by dietary fat content and full-fat soybean meal as a partial substitute for fish meal in the diet. Aquaculture 157:297-309 
Cho, C. Y., Bayley, H. S., \& Slinger, S. J. (1974). Partial replacement of herring meal with soybean meal and other changes in a diet for rainbow trout (Salmo gairdneri). Journal of the Fisheries Board of Canada, 31(9), 1523-1528

Cruz-Garcia, L., Sánchez-Gurmaches, J., Bouraoui, L., Saera-Vila, A., Pérez-Sánchez, J., Gutiérrez, J. and Navarro, I. (2011). Changes in adipocyte cell size, gene expression of lipid metabolism markers, and lipolytic responses induced by dietary fish oil replacement in gilthead sea bream (Sparus aurata L.). Comp. Biochem. Physiol. Part A Mol. Integr. Physiol. 158, 391-399.

Dabrowska, H., \& Wojno, T. (1977). Studies on the utilization by rainbow trout (Salmo gairdneri Rich.) of feed mixtures containing soya bean meal and an addition of amino acids. Aquaculture, 10(4), 297-310

Danielle Swanson, Robert Block, Shaker A. Mousa, Omega-3 Fatty Acids EPA and DHA: Health Benefits Throughout Life, Advances in Nutrition, Volume 3, Issue 1, January 2012, Pages $1-7$

Danielle Swanson, Robert Block, Shaker A. Mousa, Omega-3 Fatty Acids EPA and DHA: Health Benefits Throughout Life, Advances in Nutrition, Volume 3, Issue 1, January 2012, Pages $1-7$

Davidson, J. W., Kenney, P. B., Manor, M., Good, C. M., Weber, G. M., Aussanasuwannakul, A., \& Summerfelt, S. T. (2014). Growth performance, fillet quality, and reproductive maturity of rainbow trout (Oncorhynchus mykiss) cultured to 5 kilograms within freshwater recirculating systems. Journal of Aquaculture Research \& Development, 5(4), 1

Davidson, J., Barrows, F. T., Kenney, P. B., Good, C., Schroyer, K., \& Summerfelt, S. T. (2016). Effects of feeding a fishmeal-free versus a fishmeal-based diet on post-smolt Atlantic 
salmon Salmo salar performance, water quality, and waste production in recirculation aquaculture systems. Aquacultural Engineering, 74, 38-51.

Davidson, J., Good, C., Barrows, F. T., Welsh, C., Kenney, P. B., \& Summerfelt, S. T. (2013). Comparing the effects of feeding a grain-or a fish meal-based diet on water quality, waste production, and rainbow trout Oncorhynchus mykiss performance within low exchange water recirculating aquaculture systems. Aquacultural Engineering, 52, 45-57

Davidson, J., Kenney, P. B., Barrows, F. T., Good, C., \& Summerfelt, S. T. (2018). Fillet quality and processing attributes of postsmolt Atlantic salmon, Salmo salar, fed a fishmeal-free diet and a fishmeal-based diet in recirculation aquaculture systems. Journal of the World Aquaculture Society, 49(1), 183-196.

Enser, M. (1984). Chemistry, biochemistry and nutritional importance of animal fats. Proceedings-Easter School in Agricultural Science, University of Nottingham.

Fauconneau B, Andre' S, Chmaitilly J, Le Bail PY, Krieg F, Kaushik S (1997) Control of skeletal muscle fibres and adipose cells size in the flesh of rainbow trout. J Fish Biol 50:296-314

Fauconneau, B., Andre, S., Chmaitilly, J., Bail, P.-Y., Krieg, F. and Kaushik, S. J. (1997). Control of skeletal muscle fibres and adipose cells size in the flesh of rainbow trout. J. Fish Biol. $50,296-314$.

Fisheries, F. A. O. (2011). Aquaculture department. 2013. Global aquaculture production statistics for the year

Flynn, E. J., Trent, C. M. and Rawls, J. F. (2009). Ontogeny and nutritional control of adipogenesis in zebrafish (Danio rerio). J. Lipid Res. 50, 1641-1652. 
Fonseca-Alaniz, M. H., Takada, J., Alonso-Vale, M. I. C., \& Lima, F. B. (2006). O tecido adiposo como centro regulador do metabolismo. Arquivos Brasileiros de Endocrinologia \& Metabologia, 50(2), 216-229

Fowler, L. G. (1991). Poultry by-product meal as a dietary protein source in fall chinook salmon diets. Aquaculture, 99(3-4), 309-321

Gatlin III, D. M., Barrows, F. T., Brown, P., Dabrowski, K., Gaylord, T. G., Hardy, R. W., \& Overturf, K. (2007). Expanding the utilization of sustainable plant products in aquafeeds: a review. Aquaculture research, 38(6), 551-579

Ge'lineau A, Corraze G, Boujard T, Larroquet L, Kaushik S (2001) Relation between dietary lipid level and voluntary feed intake, growth, nutrient gain, lipid deposition and hepatic lipogenesis in rainbow trout. Reprod Nutr Dev 41:487-503

Gerrard, D. E., \& Grant, A. L. (2003). Principles of animal growth and development. Kendall Hunt.

Glencross, B., Hawkins, W., Evans, D., Rutherford, N., McCafferty, P., Dods, K., \& Hauler, R. (2011). A comparison of the effect of diet extrusion or screw-press pelleting on the digestibility of grain protein products when fed to rainbow trout (Oncorhynchus mykiss). Aquaculture, 312(1-4), 154-161

Green HS, Selivonchick DP (1987) Lipid metabolism in fish. Prog Lipid Res 26:53 85

Hamm R. 1977. Changes of muscle proteins during the heating of meat. In: Hoyem T, KvaleO, editors. Physical, chemical and biological changes in food caused by thermal processing.Oslo: Applied Science Publishers. p 101-34 
He, A.-Y., Ning, L.-J., Chen, L.-Q., Chen, Y.-L., Xing, Q., Li, J.-M., Qiao, F., Li, D.-L., Zhang, M.-L. and Du, Z.-Y. (2015). Systemic adaptation of lipid metabolism in response to lowand high-fat diet in Nile tilapia (Oreochromis niloticus). Physiol. Rep. 3, e12485

Hernández, A. J., \& Roman, D. (2016). Phosphorus and nitrogen utilization efficiency in rainbow trout (Oncorhynchus mykiss) fed diets with lupin (Lupinus albus) or soybean (Glycine max) meals as partial replacements to fish meal. Czech Journaj Animal Science, 61(2), 67-74.

Jezierska B, Hazel JR, Gerking SD (1982) Lipid mobilization during starvation in the rainbow trout, Salmo gairdneri Richardson, with attention to fatty acids. J Fish Biol 21:681-692

Jobling M, Johansen SJS (2003) Fat distribution in Atlantic salmon Salmo salar L. in relation to body size and feeding regime. Aquac Res 34:311-316

Jobling M, Koskela J, Savolainen R (1998) Influence of dietary fat level and increased adiposity on growth and fat deposition in rainbow trout, Oncorhynchus mykiss (Walbaum). Aquac Res 29:601-607

Jobling M, Larsen A, Andreassen B, Sigholt T, Olsen RL (2002) Influence of a dietary shift on temporal changes in fat deposition and fatty acid composition of Atlantic salmon postsmolt during the early phase of sea water rearing. Aquac Res 33:875-889

Karakatsouli, N. (2012). An overview of the use of fatty acids in fish farming research during the last decade, with particular emphasis on fish quality. Journal of the World Aquaculture Society, 43(3), 291-320.

Katikou P, Hughes SI, Robb DHF (2001) Lipid distribution within Atlantic salmon (Salmo salar) fillets. Aquaculture 202:89-99 
Kiessling A, Kiesling KH, Storebakken T, A ${ }^{\circ} \mathrm{sga}^{\circ} \mathrm{rd}$ T (1991) Changes in the structure and function of the epaxial muscle of rainbow trout (Oncorhynchus mykiss) in relation to ration and age III. Chemical composition. Aquaculture 93:373-387

Kiron, V., Phromkunthong, W., Huntley, M., Archibald, I., \& De Scheemaker, G. (2012). Marine microalgae from biorefinery as a potential feed protein source for Atlantic salmon, common carp and whiteleg shrimp. Aquaculture Nutrition, 18(5), 521-531

Konige, M.,Wang, H. and Sztalryd, C. (2014). Role of adipose specific lipid droplet proteins in maintaining whole body energy homeostasis. Biochim. Biophys. Acta - Mol. Basis Dis. $1842,393-401$

Liland, N. S., Hatlen, B., Takle, H., Venegas, C., Espe, M., Torstensen, B. E., \& Waagbø, R. (2015). Including processed poultry and porcine by-products in diets high in plant ingredients reduced liver TAG in A tlantic salmon, S almo salar L. Aquaculture Nutrition, 21(5), 655-669

Lim, S. J., \& Lee, K. J. (2009). Partial replacement of fish meal by cottonseed meal and soybean meal with iron and phytase supplementation for parrot fish Oplegnathus fasciatus. Aquaculture, 290(3-4), 283-289

Manor, M. L., Weber, G. M., Cleveland, B. M., \& Kenney, P. B. (2014). Effects of feeding level and sexual maturation on fatty acid composition of energy stores in diploid and triploid rainbow trout (Oncorhynchus mykiss). Aquaculture, 418, 17-25

Moon, S. S., Yang, H. S., Park, G. B., \& Joo, S. T. (2006). The relationship of physiological maturity and marbling judged according to Korean grading system to meat quality traits of Hanwoo beef females. Meat Science, 74(3), 516-521

Navarro I, Gutie' rrez J (1995) Fasting and starvation. In: Ho-chachka W, Mommsen T (eds) Biochemistry and molec-ular biology of fishes, vol 4. Elsevier, London, pp 393-433 
Naylor, R. L., Hardy, R. W., Bureau, D. P., Chiu, A., Elliott, M., Farrell, A. P., ... \& Nichols, P. D. (2009). Feeding aquaculture in an era of finite resources. Proceedings of the National Academy of Sciences, 106(36), 15103-15110

Nelson, D. L., Lehninger, A. L., \& Cox, M. M. (2008). Lehninger principles of biochemistry. Macmillan.

Nelson, D.L., Cox. M.M. 2013. Lehninger Principles of Biochemistry. 6th ed. W.H. Freeman and CompanyNew York, NY

Ng, W. K., Lim, H. A., Lim, S. L., \& Ibrahim, C. O. (2002). Nutritive value of palm kernel meal pretreated with enzyme or fermented with Trichoderma koningii (Oudemans) as a dietary ingredient for red hybrid tilapia (Oreochromis sp.). Aquaculture Research, 33(15), 1199-1207

Ohlrogge, J. B., \& Jaworski, J. G. (1997). Regulation of fatty acid synthesis. Annual review of plant biology, 48(1), 109-136

Ohlrogge, J. B., \& Jaworski, J. G. (1997). Regulation of fatty acid synthesis. Annual review of plant biology, 48(1), 109-136

Paaver, T., Gross, R., \& Ilves, P. (2004). Growth rate, maturation level and flesh quality of three strains of large rainbow trout (Oncorhynchus mykiss) reared in Estonia. Aquaculture International, 12(1), 33-45

Palmeri G, Turchini GM, Keast R, Marriorr PJ, Morrisson P,DeSilva SS (2008) Effects of starvation and water quality on the purging process of farmed Murray Cod (Maccullochella peelii peelii). J Agric Food Chem 56:9037-9045

Palmeri, G., Turchini, G. M., \& De Silva, S. S. (2007). Lipid characterisation and distribution in the fillet of the farmed Australian native fish, Murray cod (Maccullochella peelii peelii). Food Chemistry, 102(3), 796-807 
Proença, A. R. G., Sertié, R. A. L., Oliveira, A. C., Campaãa, A. B., Caminhotto, R. O., Chimin, P., Lima, F. B., Proença, A. R. G., Sertié, R. A. L., Oliveira, A. C. et al. (2014). New concepts in white adipose tissue physiology. Brazilian J. Med. Biol. Res. 47, 192-205

Robinson, J. S., \& Mead, J. F. (1973). Lipid absorption and deposition in rainbow trout (Salmo gairdnerii). Canadian journal of biochemistry, 51(7), 1050-1058

Rutkowski, J. M., Stern, J. H. and Scherer, P. E. (2015). The cell biology of fat expansion. J. Cell Biol. 208, 501-512

Salem, M., Kenney, P. B., Rexroad, C. E., \& Yao, J. (2006). Molecular characterization of muscle atrophy and proteolysis associated with spawning in rainbow trout. Comparative Biochemistry and Physiology Part D: Genomics and Proteomics, 1(2), 227-237

Salmerón, C., Johansson, M., Angotzi, A. R., Rønnestad, I., Jö nsson, E., Bjö rnsson, B. T., Gutiérrez, J., Navarro, I. and Capilla, E. (2015). Effects of nutritional status on plasma leptin levels and in vitro regulation of adipocyte leptin expression and secretion in rainbow trout. Gen. Comp. Endocrinol. 210, 114-123

Salze, G., McLean, E., Battle, P. R., Schwarz, M. H., \& Craig, S. R. (2010). Use of soy protein concentrate and novel ingredients in the total elimination of fish meal and fish oil in diets for juvenile cobia, Rachycentron canadum. Aquaculture, 298(3-4), 294-299

Schubring R. 2008. Comparative study of the DSC pattern, color, texture and waterbinding capacity of rainbow trout muscle during heating. J Food Process Preserv 32:190-218

Sealey, W. M., Gaylord, T. G., Barrows, F. T., Tomberlin, J. K., McGuire, M. A., Ross, C., \& St-Hilaire, S. (2011). Sensory analysis of rainbow trout, Oncorhynchus mykiss, fed enriched black soldier fly prepupae, Hermetia illucens. Journal of the World Aquaculture Society, 42(1), 34-45 
Sheridan, M. A. (1988). Lipid dynamics in fish: aspects of absorption, transportation, deposition and mobilization. Comparative Biochemistry and Physiology Part B: Comparative Biochemistry, 90(4), 679-690

Sheridan, M. A., \& Kao, Y. H. (1998). Regulation of metamorphosis-associated changes in the lipid metabolism of selected vertebrates. American Zoologist, 38(2), 350-368

Spalding, K. L., Arner, E., Westermark, P. O., Bernard, S., Buchholz, B. A., Bergmann, O., Blomqvist, L., Hoffstedt, J., Näslund, E., Britton, T. et al. (2008). Dynamics of fat cell turnover in humans. Nature 453, 783-787

Swanson, D., Block, R., \& Mousa, S. A. (2012). Omega-3 fatty acids EPA and DHA: health benefits throughout life. Advances in nutrition, 3(1), 1-7

Tacon, A. G., \& Metian, M. (2008). Global overview on the use of fish meal and fish oil in industrially compounded aquafeeds: Trends and future prospects. Aquaculture, 285(1-4), 146158

Torstensen BE, Espe M, Stubhaug I, Lie Ø (2011) Dietary plant proteins and vegetable oil blends increase adiposity and plasma lipids in Atlantic salmon (Salmo salar L.). Br J Nutr 106:633647

Umino, T., Nakagawa, H. and Arai, K. (1996). Development of adipose tissue in the juvenile red sea bream. Fish. Sci. 62, 520-523

Wang, Y., Kong, L. J., Li, C., \& Bureau, D. P. (2006). Effect of replacing fish meal with soybean meal on growth, feed utilization and carcass composition of cuneate drum (Nibea miichthioides). Aquaculture, 261(4), 1307-1313

Weil C, Blaise O, Breton B, Carre' F, Fauconneau B, Gomez JM, Le Bail PY, Le Gac F (2000) Puberty in rainbow trout: role of growth and metabolic hormones. In: Proceedings of the 
molecular mechanisms of morphogenesis in the early development of fish. National Research Institute of Aquaculture, Nansei, Mie Japan, pp 34-36

Weil, C., Lefèvre, F. and Bugeon, J. (2013). Characteristics and metabolism of different adipose tissues in fish. Rev. Fish Biol. Fish. 23, 157-173

Wood, J.D., Richarson, R.I., Nute, G.R., Fisher, A.V., Campo, M.M., Kasapidou, E., Sheard, P.R., Enser, M. 2003. Effects of fatty acids on meat quality: a review. Meat Science. 66, $21-32$

Yamaguchi, T., Omatsu, N., Morimoto, E., Nakashima, H., Ueno, K., Tanaka, T., \& Osumi, T. 2007. CGI-58 facilitates lipolysis on lipid droplets but is not involved in the vesiculation of lipid droplets caused by hormonal stimulation. Journal of lipid research, 48(5), 1078-1089 